\title{
Sistem Pendukung Keputusan Penilaian Kinerja Karyawan Dengan Menerapkan Metode SAW Pada PT. Gada Agni Indonesia
}

\author{
Henderi $^{1}$, Ar Ridho Gusti ${ }^{2}$, Frama Yenti ${ }^{3}$ \\ ${ }^{1}$ Dosen Tetap Universitas Raharja ${ }^{2,3}$ Mahasiswa Magister Teknik Informatika Universitas Raharja

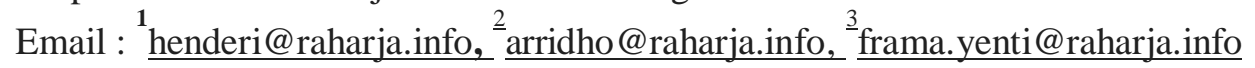

\begin{abstract}
Abstrak
Karyawan yaitu faktor pendukung dalam perusahaan, dengan adanya karyawan yang mempunyai standar kualifikasi perusahaan dengan demikian diharapkan produktivitas perusahaan meningkat. Pengukuran kinerja karyawan di sebuah perusahaan sangat penting untuk evaluasi dan perencanaan di masa yang akan datang. Sistem Penilaian berpengaruh dalam beberapa faktor : umur, ras, jenis kelamin serta performa berpengaruh akan nilai karyawan. Jika menginginkan informasi yang akurat tentang kinerja karyawan, dibutuhkan suatu proses otomatisasi dengan menggunakan teknologi. Di penelitian ini kami sebagai penulis akan menerapkan sebuah metode SAW (Simple Additive Weighting ) berpatokan terhadap nilai kriteria dan nilai bobot yang telah ditentukan pada PT Gada Agni Indonesia untuk penilaian kinerja karyawan dengan tujuan sebagai bahan pertimbangan bagi manajeman khususnya bagian Manager HRD \&GA untuk mengambil keputusan guna memberikan penilaian dengan kriteria-kriteria yang telah ditentukan diantaranya : tanggung jawab, kemampuan komunikasi, inisiatif, kehadiran, kerja keras dan sikap. Dengan diadakannya penelitian ini diharapkan perusahaan akan mendapatkan bobot kriteria dan menghasilkan rangking alternatif untuk penilalian kinerja karyawan. Hasil dari penelitian ini terbentuk suatu sistem pendukung keputusan yang bisa mengolah data penilaian kinerja karyawan dalam menentukan penilaian menjadi sebuah pertimbangan yang sangat valid. Dari hasil penilitian ini diharapkan pengambilan keputusan menjadi terbentuk untuk menilai karyawan terbaik PT Gada Agni Indonesia.
\end{abstract}

Kata Kunci : Sistem Penunjang Keputusan, SAW, Penilaian Kinerja karyawan

\begin{abstract}
Employees are a supporting factor in a company or agency, because with employees who have company qualification standards, company productivity is expected to increase. Measurement of employee performance in a company is very important for evaluation and planning in the future. Assessment is often influenced by several factors, including : age, race, gender and appearance which greatly affect the value of employees. To obtain fast and accurate information on employee performance in the appropriate employee performance appraisal, an automation process using technology is needed. In this study, we as writers will apply a SAW (Simple Additive Weighting) methode based on the criteria and weight values that have been determined at PT Gada Agni Indonesia for employet performance assessment with the aim of being considered for management, especially the HRD \& GA manager to take the decision to provide an assessment with the agreed criteria, namely responsibility, communication skills, initiative, attendance, working age and attitude. By holding this research, it is hoped that the company will get the weight of the criteria and produce alternative rankings for evaluating employeet performance. The results of this study are in the form of a decision support system that can process employee performance appraisal data in determining the assessment into a valid consideration. From the results of this study, it is expected that decision-making will be formed in the assessment of employees at PT Gada Agni Indonesia.
\end{abstract}

Keywords: Decision Support Systems, SAW, Employee performance appraisal 


\section{Pendahuluan}

Stewart, (1998, hal. 125-126) mengatakan, Proses pemantau dan penilaian dilakukan secara terus menerus menjadi ciri manajemen yang dijalankan, baik berupa penilaian maupun yang dinilai dengan memperhatikan standar yang telah di terapkan yang telah ditetapkan ${ }^{[3]}$. Decision Support System (DSS) dinyatakan oleh Michael S. Scott Morton di 1970 dengan istilah Management Decision System (Sprague and Watson: 1993: 4) (Turban: 1995) (McLeod: 1995) ${ }^{[1]}$ Sebenarnya DSS di rancang guna mendukung semua tahapan dalam pengambilan keputusan dimulai dari mengidentifikasi maslah, memilih data yg relevan, menentukan pendekatan yang dipakai dalam tahapan proses pengambilan keputusan sampai dengan mengevaluasi pemilihan secara alternatif [2], [4], [5].

Proses penilaian kinerja dalam suatu instansi adalah sebuah tahap evaluasi kinerja yang bisa meningkatkan kualivikasi perusahaan untuk kelangsungan sebuah aktivitas di perusahaan. Setiap instansi diperlukan sistem penilaian kinerja untuk menentukan kinerja dari para pegawai dari sisi kualitas dan tanggung jawab atas pekerjaanya. Unsur-unsur penilaian kinerja karyawan berdasarkan pada kriteria yang sudah ditetapkan diantaranya tanggung jawab, kemampuan komunikasi, inisiatif, kehadiran, usia kerja dan sikap[6]. Sistem penunjang keputusan yaitu sebuah proses untuk membantu pengambilan keputusan [7]. System penunjang keputusan yaitu suatu system yang berguna dalam pen gambilan keputusan organisasi yang memanfaatkan sebuah teknologi guna proses pemilihan alternatif terbaik dari beberapa alternatif dengan cara sistematis yang di pakai untuk memecahkan suatu masalah ${ }^{[8], ~[9], ~[10], ~[11] . ~ M e t o d e ~}$ yang dapat diterapkan pada Sistem Pendukung Keputusan yaitu Simple Additive Weighting (SAW) yang merupakan salah satu metode untuk menyelesaikan masalah multi-attribute decision making. Metode yang dipakai untuk menilai kinerja karyawan yaitu metode SAW, alasan kenapa kami lebih memilih metode ini dibandingkan metode yang lain terletak pada kempuan dalam menilai secara cepat dan akurat yang berdasarkan pada nilai bobot kriteria yang sudah ditentukan ${ }^{[12]}$. Konsep dasar metode SAW yaitu menelusuri jumlah nilai terbobot dari nilai ranting kinerja dari setiap atribut ${ }^{[13][14]}$. Di penelitian ini dirancang sistem penunjang keputusan penilaian kinerja karyawan terbaik dengan menerapkan metode Simple Additive Weighting (SAW), dengan adanya metode ini bisa menjadi pemencahan masalah untuk para karyawan berdasrkan nilai kriteria dan bobot yang sudah di tetapkan perusahaan sebelum proses perhitungan untuk mencari karyawan terbaik di PT Gada Agni indonesia.

\section{Literatur Review}

Penelitian yang dijalankan oleh ${ }^{[7]}$ Metode metode yang dipakai untuk sistem penunjang keputusan ini yaitu metode literative. metode literative adalah metode dimana tahap pengembangannya sistemnya menggunakan teknik pengulangan, dimana ini dilakaukan sampai memperoleh hasil yang dinginkan atau hasil yang maksimal.

Penelitian yang dijalankan oleh [13] Sistem penunjang keputusan pemilihan karyawan menerapkan metode prototype. Metode prototype, dipakai karen tahap mengembangkan sisytem menjadi lebih cepat.

Penelitian yang dijalankan oleh [8] [15] [16] Teknik analisis yang di pakai dalam metode ini yaitu metode AHP, metode SAW dan analisis deskriptis. Analisis deskriptis didapatkan dengan survei atau kuesioner. Metode AHP untuk mencari bobot kriteria dan metode SAW untuk perangkingan nilai karyawan berdasarkan kriteria dan mengurutkan nilai yang terkecil hingga yang tertinggi untuk mengetahui karyawan terbaik.

\section{Metode Penelitian}

Penilaian kinerja karyawan pada PT. Gada Agni Indonesia dengan menggunakan sistem penilaian dari kuesioner yang akan dinilai dari masing-masing karyawan kepada karyawan lain. Dengan menerapkan metode SAW Simple Additive Weighting).bPenelitian disini memakai beberapa langkah dalam mencapai 
tujuan dari penelitian. Dimulai dengan melakukan wawancara, Observasi, menganalisis berkas berkas, study pustaka dan instrumentasi ${ }^{[8]}[15][16]$.

\section{Pengumpulan Data}

\section{Wawancara}

Wawancara dilakukan dengan mengajukan beberapa pertanyaan ke bagian operations managerBpk Budi Firnandi agar dapat mengetahui proses yang ada di PT Gada Agni Indonesia.

\section{Angket atau kuesioner}

Yaitu teknik pengumpulan data berupa formulir yang berisikan pertanyaan yang akan dia ajaukan kepada karyawan di PT Gada Agni Indonesia, pertanyaan tersebut dibuat secara terstruktur melalui mutiple choice. dimana setiap karyawan melakukan penilaian terhadap karyawan yang lain dengan real.

\section{Dokumentasi}

Adalah pengumpulan data diman peneliti mendeteksi secara tertulis mengecek absensi karyawan. Metode ini dipakai untuk menilai kedisiplinan untuk para karyawan.

\section{Model Perancangan \\ Metode Simple Additive Weighting (SAW)}

Metode SAW disebut juga dengan istilah metode penjumlahan terbobot. Metode ini mengharuskan si pembuat keputusan menentukan bobot dari setiap atribut. ${ }^{[15]}$ Pengertian metode SAW yaitu jumlah terbobot dari rating kinerja pada setiap alternatif pada keseluruhan atribut. (Kusumadewi, 2006:74) Metode SAW memerlukan proses normalisasi matriks keputusan ke skala yang bisa dibandingkan dengan ranting alternatif yang sudah ada. ${ }^{[16]}$ Patokan ini dinamis dan nilai bobot kriteria bisa dirubah sesuai kemauan pemakai. Metode SAW memerlukan serangkaian langkah langkah normalisasi matrik keputusan $(\mathrm{X})$ kedalam skala yang bisa dibandingkan dengan seluruh alternatik yang susah ada ${ }^{[17] .}$

$$
r_{i j}= \begin{cases}\frac{x_{i j}}{\operatorname{Maxx}_{i j}} & \text { jika j ialah atribut keuntungan (benefit) } \\ \frac{\operatorname{Minx}_{i j}}{x_{i j}} & \text { jika j ialah atribut biaya (cost) }\end{cases}
$$

\section{Perancangan Dan Implementasi}

\section{Penghitngan Dengan Metode SAW}

Adapun nilai bobot yang di perlukan untuk menunjukan siapa yang terpilih, denga diujinya 5 karyawan untuk uji coba untuk menerapkan metode SAW ini sebagai karyawan yang terbaik.

Table 1. Table Nilai Alternatif Perkriteria

\begin{tabular}{|l|c|c|c|c|c|c|}
\hline $\begin{array}{l}\text { Alternatif/ } \\
\text { Kriteria }\end{array}$ & $\begin{array}{c}\text { Tanggung } \\
\text { jawab }\end{array}$ & Komunikasi & Inisiatif & Kehadiran & $\begin{array}{c}\text { Lama } \\
\text { Kerja }\end{array}$ & Sikap \\
\hline Tremayne & 100 & 48 & 32 & 90 & 0 & 80 \\
\hline Elsbeth & 100 & 64 & 80 & 100 & 100 & 80 \\
\hline Rossie & 67 & 48 & 64 & 100 & 100 & 48 \\
\hline Selig & 67 & 48 & 64 & 100 & 100 & 64 \\
\hline Cristiano & 33 & 48 & 48 & 100 & 100 & 48 \\
\hline
\end{tabular}

Tabel 1 menginformasikan tentang nilai alternatif kriteria, Penilaian ini didasarkan pada 5 kriteria yang diajukan diantaranya tanggung jawab, komunikasia, inisiatif, kehadiran, lama kerja dan sikap. 
Masing masing kriteria dapat dinilai oleh karyawan lain sesuai dengan penilaian dari tiap tiap karyawan, Hasil penilaian ini yang akan di jadikan acuan untuk memperoleh karyawan terbaik. Setelah di tentukan nilai masing masing kriteria setiap karyawan, maka dapat melakukan matriks normalisasi untuk menghitung nilai masing kriteria. Dibawah ini yaitu penghitungan salah satu kriteri a, maka didapatkan nilai dari alternatif tersebut.

Perhitungan Kriteria Nilai Tanggung Jawab

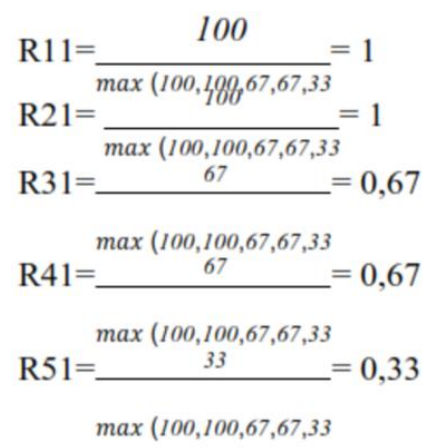

Selanjutnya menginformasikan hasil normalisasi penghitungan nilai dari masing masing matrik kriteria.

Tabel 2. Matrik Perbandingan Kepentingan Antar Kriteria

\begin{tabular}{|l|c|c|c|c|c|c|}
\hline Name & $\begin{array}{l}\text { Tanggung } \\
\text { Jawab }\end{array}$ & Komunikasi & Inisiatif & $\begin{array}{l}\text { Kehadira } \\
\mathbf{n}\end{array}$ & Lama Kerja & Sikap \\
\hline Tremayne & 1 & 0,75 & 0,4 & 0,9 & 0 & 1 \\
\hline Elsbeth & 1 & 1 & 1 & 1 & 1 & 1 \\
\hline Rossie & 0,67 & 0,75 & 0,8 & 1 & 1 & 0,6 \\
\hline Selig & 0,67 & 0,75 & 0,8 & 1 & 1 & 0,8 \\
\hline Cristiano & 0,33 & 0,75 & 0,6 & 1 & 1 & 0,6 \\
\hline Bobot & 0,330 & 0,223 & 0,190 & 0,118 & 0,083 & 0,057 \\
\hline
\end{tabular}

Tabel 2 menginformasikan bahwa diperolehnya hasil normalisasi penghitungan nilai dari masing masing kriteria dimana setiap pegawai dapat menilai setiap pegawai yang lain dengan nyata dengan cara menginput nilai kriteria dari beberapa kriteria penilaian berdasarkan bobot kriteria yang sudah ditetapkan. Perhitungan dilakukan dengan rumus SAW dimana nilai kriteria tanggung jawab 100 dibagi dengan nilai tertinggi dari kriteria tanggung jawab yaitu 100, maka diperoleh hasil penghitungan (1). Dari hasil penghitungan matrik normalisasi di atas, jika nilai $\mathrm{R}$ diperoleh, kemudina proses nilai preferensi untuk semua karyawan.

a. Tremayne

$=\{(1 \times 0,330)+(0,750 \times 0,223)+(0,4 \times 0,190)+(0,9 \times 0,118)+(0 \times 0,083)+(1 \times 0,057)\}$

$=(0,330+0,1672+0,076+0,1062+0+0,057)$

$=0,7364$

Dari hasil pencarian diatas maka diperoleh perangkingan dibawah ini. 
Tabel 3. Hasil Perangkingan

\begin{tabular}{|l|c|c|c|c|c|c|c|c|}
\hline Name & C1 & C2 & C3 & C4 & C5 & C6 & \multicolumn{2}{|c|}{ Total Rank } \\
\hline Tremayne & 1 & 0,75 & 0,4 & 0,9 & 0 & 1 & 0,7364 & 4 \\
\hline Elsbeth & 1 & 1 & 1 & 1 & 1 & 1 & 1,001 & 1 \\
\hline Rossie & 0,67 & 0,75 & 0,8 & 1 & 1 & 0,6 & 0,77555 & 3 \\
\hline Selig & 0,67 & 0,75 & 0,8 & 1 & 1 & 0,8 & 0,78695 & 2 \\
\hline Cristiano & 0,33 & 0,75 & 0,6 & 1 & 1 & 0,6 & 0,62535 & 5 \\
\hline Bobot & 0,330 & 0,223 & 0,190 & 0,118 & 0,083 & 0,057 & & \\
\hline
\end{tabular}

Tabel 3 menginformasikan tentang perangkingan dari nilai bobot kriteria dan rangking akhir penghitungan normalisasi yang sudah diperoleh. Penghitungan dilakukan dengan mengalihkan nilai bobot dari setiap nilai baris nilai matriks normalisasi. Sebagai contoh nilai kriteria tanggung jawab di kali dengan nilai bobot, begitu juga dengan kriteria yang lainnya, setelah nilai masing masih kriteria di kalikan, maka semua nilai yang sudah di dapat dijumlahkan dan hasilnya akan dijadikan patokan untuk perangkingan akhir. Dari hasil penghitungan diatas sehingga dapat disimpulkan bahwa nilai terbesar penghitungan nilai bobot kriteria diperoleh Elisabeth sebagai alternatif terbaik dengan nilai 1,001.

\section{Pengujian dan Implementasi System}

Berikut ini yaitu rancangan dari interface system penunjang keputusan dengan metode SAW untuk menentukan penilaian kinerja karyawan.

\section{Tampilan Kuisoner Penilaian Pegawai}

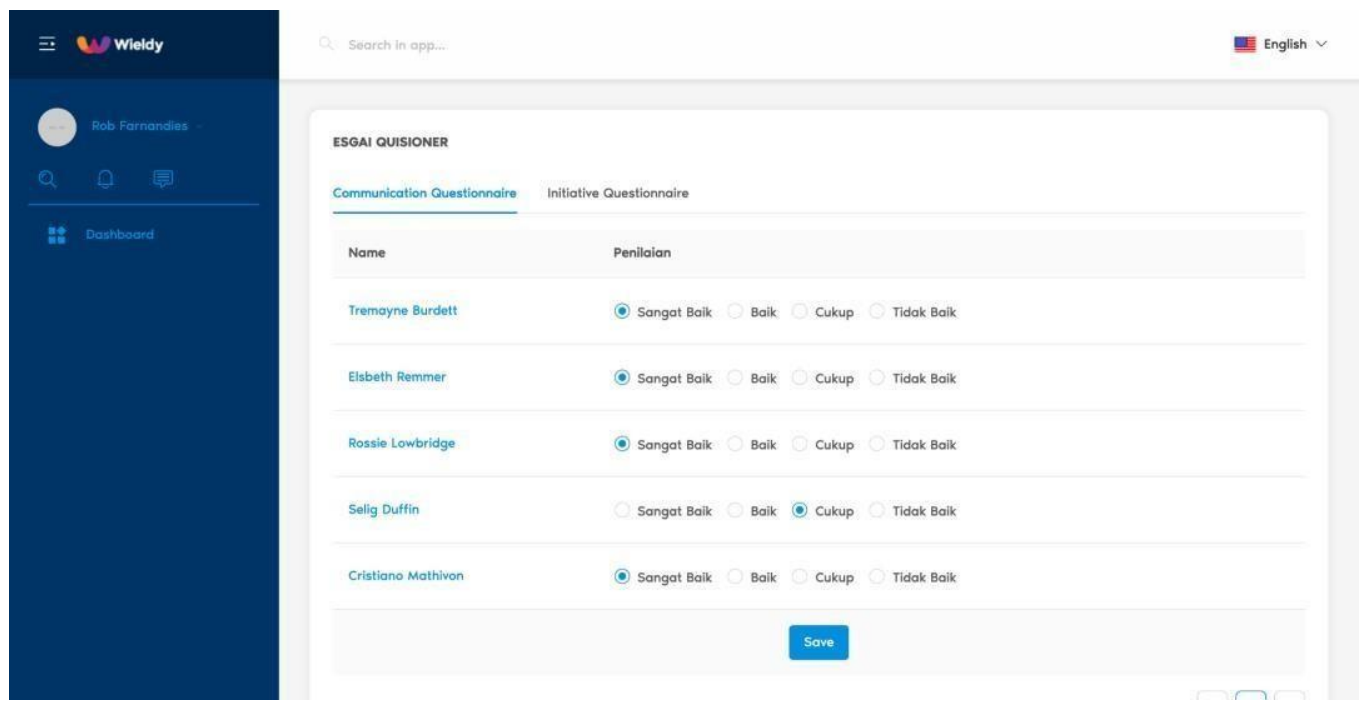

Gambar 1. Tampilan Kuesioner

Form kuesioner penilaian karyawan digunakan user mengakses penilaian terhadap satu karyawan ke karyawan yang lain dan tidak bisa menilai diri sendiri. Fungsi Form Kuisioner ini untuk menilai masing masing kriteria dari tiap karyawan berdasarkan komunikasi dan inisiatif. Kelebihan dari tampilan ini nilai bobot kriteria dapat diubah sesuai dengan keinginan. Form kuesioner hanya diberikan akses ke karyawan, karena hanya sesama karyawan yang bisa mengisi dan melihat form kuesioner. 


\section{Tampilan Halaman Dashboard dan terdapat 4 Menu Grid}

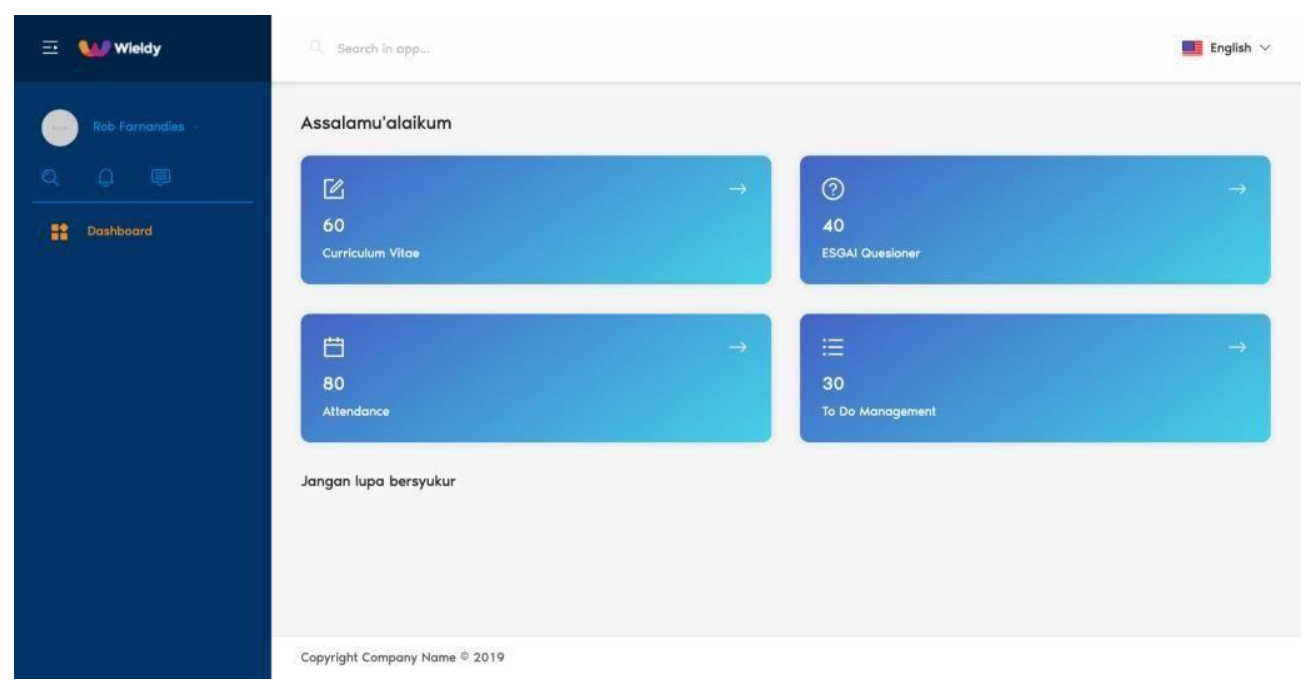

\section{Gambar 2. Tampilan Dashboard dan 4 Menu Grid}

Gambar 2. Menunjukan bahwa aplikasi pada tampilan dashboard memiliki 4 (empat) menu grid yaitu, Curriculum Vitae, ESGAI Questioner, Attendance, To Do management. Masing-masing dari ke empat menu ini memiliki kegunaan yang berbeda. Seperti Curriculum Vitae digunakan untuk melihat informasi pribadi, keluarga, kontak, pendidikan, dan deskripsi. Fungsi menu Curriculum Vitae untuk mendapatkan nilai kriteria working age. Menu ESGAI Kuesioner digunakan user melihat dan mengisi form kuesioner penilaian karyawan yang lainnya. Fungsi menu ESGAI Kuesioner untuk mendapat nilai kriteria komunikasi, inisiatif dan sikap. Menu Attendance digunakan untuk absensi cuti dari setiap karyawan. Fungsi menu Attendance untuk mendapatkan nilai kriteria absensi. Dan menu Todo Management digunakan user untuk melihat proses pengerjaan selama bekerja. Fungsi menu Todo Management untuk mendapatkan nilai kriteria tanggung jawab. Menu grid hanya bisa dilihat oleh karyawan, karena menu ini untuk menuju ke informasi karyawan.

\section{Tampilan Menu SDM}

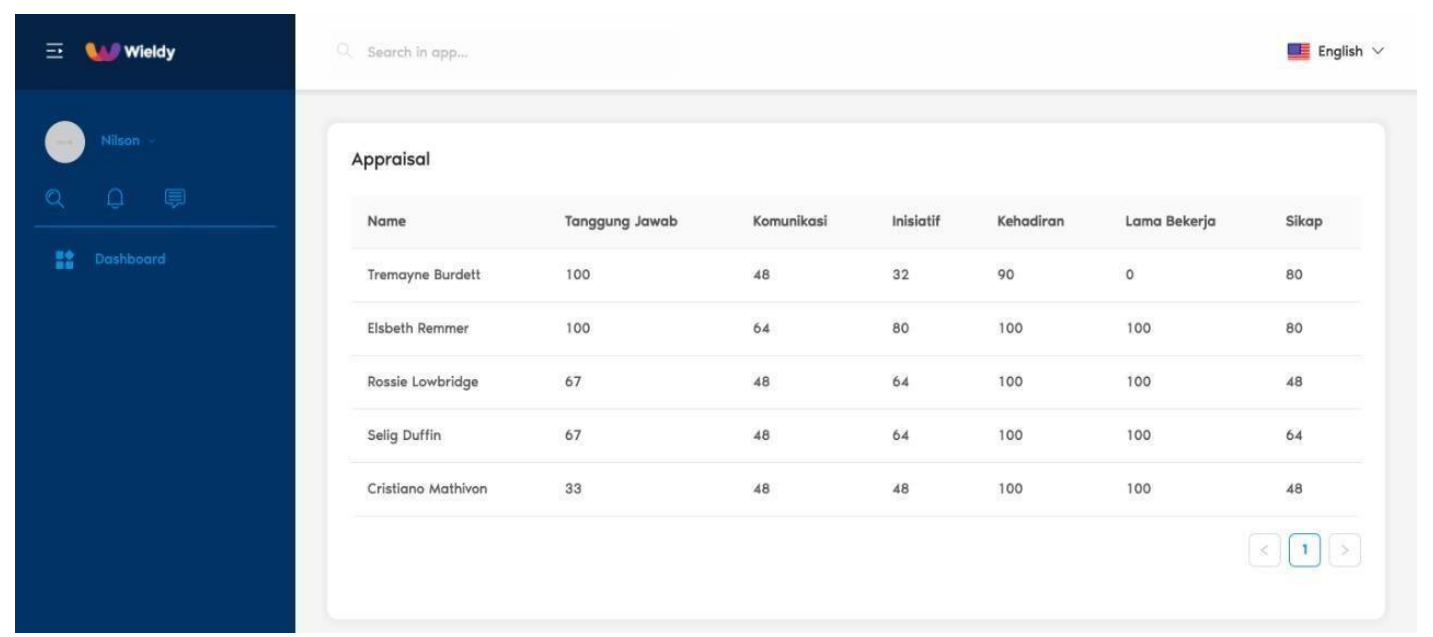

Gambar 3.Tampilan Nilai Alternatif Per Kriteria 
Di tampilan halaman ini digunakan user untuk melihat nilai informasi sesuai bobot pada data crips yang telah ditentukan. Fungsi halaman ini dimana user mendapatkan kesimpulan penilaian dari proses input yang telah dilakukan oleh semua karyawan. Halaman ini hanya diakses oleh SDM, karena hanya SDM yang bisa melihat kesimpulan nilai yang sudah di input karyawan.

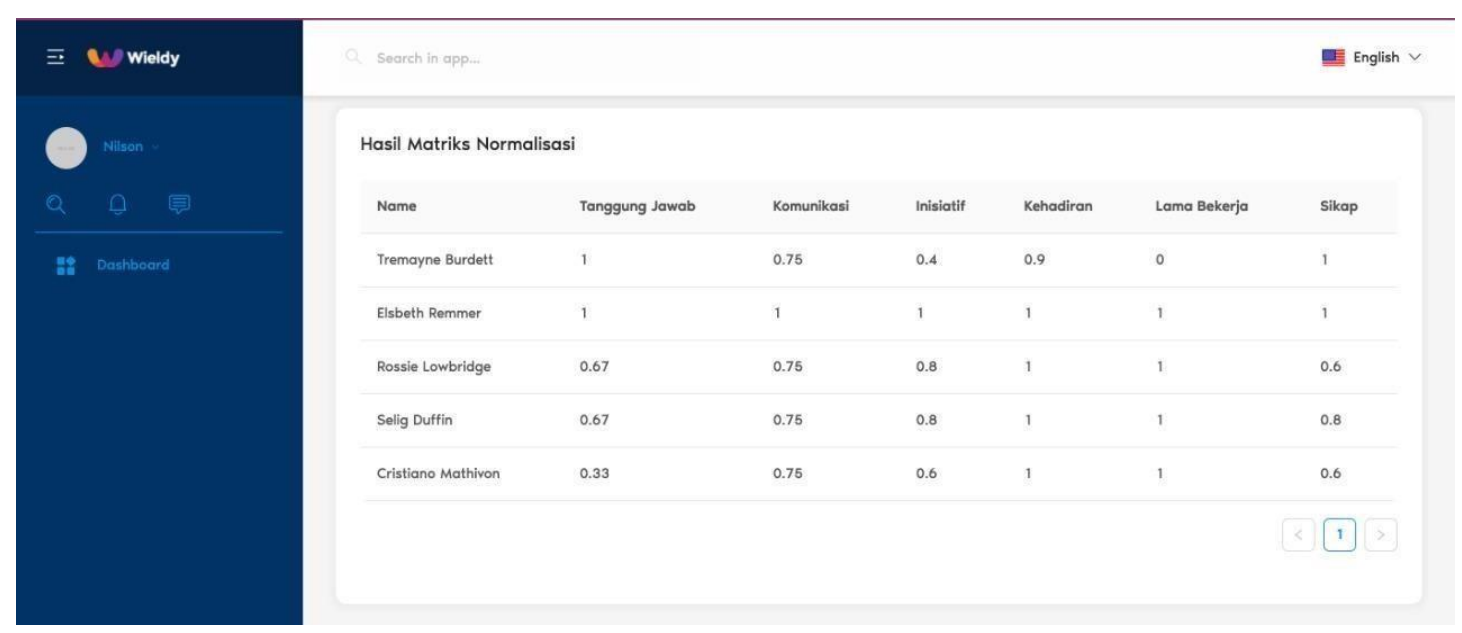

\section{Gambar 4. Tampilan Hasil Penghitungan Matrik Normalisasi}

Di halaman ini digunakan user untuk melihat hasil normalisasi penghitungan nilai dari masing masing kriteria yang diajukan. dimana setiap pegawai menilai masing-masing rekan kerjanya agar mendapatkan hasil penilaian kerja secara real dari satu pegawai ke pegawai lain dengan cara menginput nilai terhadap kriteria dari beberapa kriteria penilaian. Halaman ini hanya diakses oleh SDM, karena SDM membutuhkan informasi hasil matriks normalisasi.

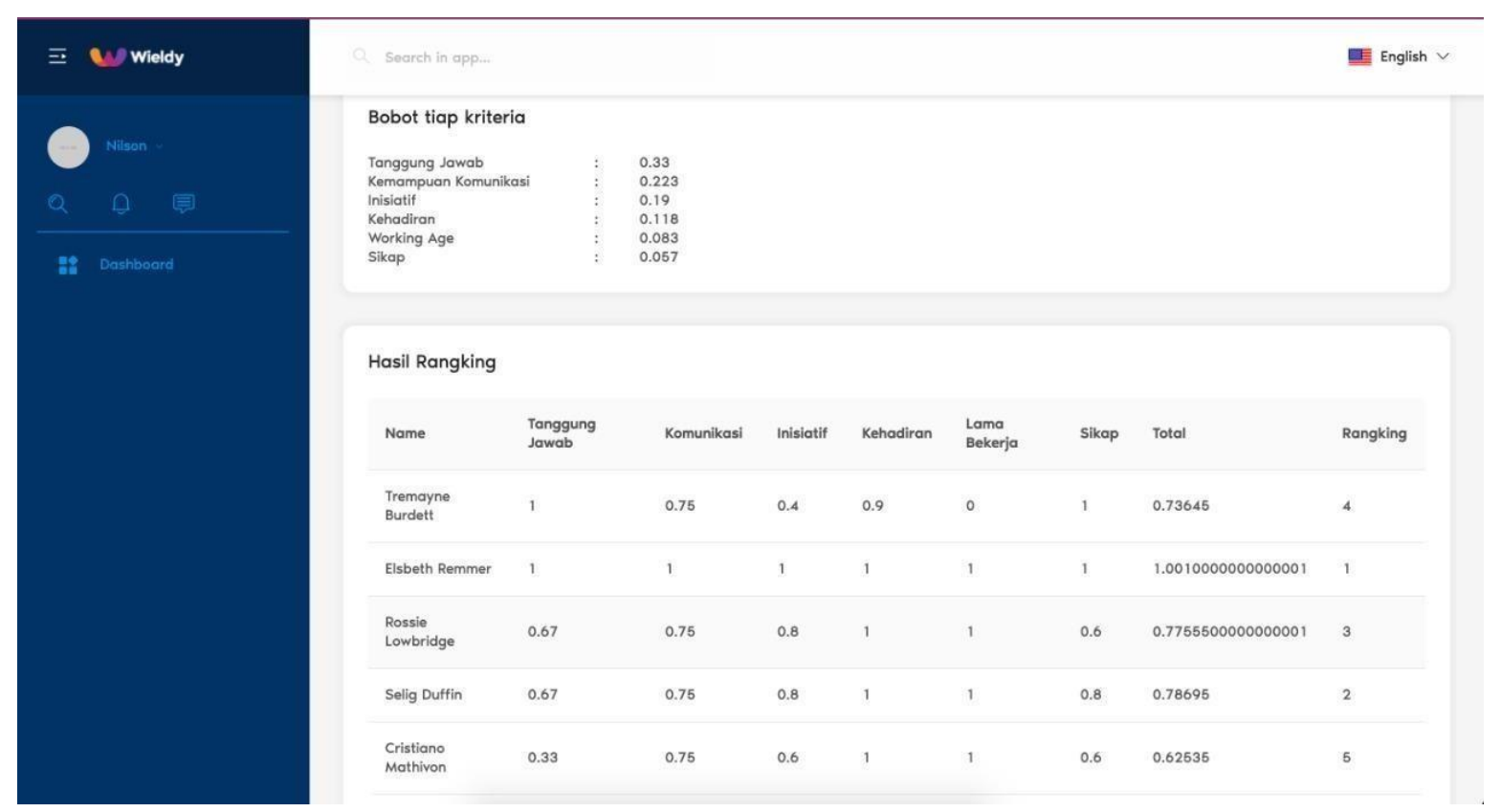

Gambar 5. Tampilan Hasil Perhitungan Rangking 
Di halaman ini digunakan user untuk melihat bobot tiap kriteria dan rangking akhir dari penghitungan normalisasi. Fungsi bobot nilai kriteria untuk menentukan seberapa penting kriteria tersebut dan diperoleh lah nilai rangking dari masing masing kriteria. Fungsi rangking untuk memudahkan user memilih karyawan mana yang terbaik. Halaman ini hanya diakses oleh SDM, karena SDM yang akan menentukan karyawan yang terbaik.

\section{Kesimpulan}

Penelitian ini mendemonstrasikan sistem penunjang keputusan untuk menentukan karyawan terbaik berdasarkan hasil penilaian kinerja karyawan. Sistem penunjang keputusan yang dihasilkan melalui penelitian ini terbukti mempermudah bagian Human Resource Development dalam menentukan pemilihan karyawan terbaik berdasarkan kriteria penilaian kinerja yang telah ditetapkan. Selain itu, sistem penunjang keputusan yang dihasilkan mempermudah pegawai dalam hal memberikan penilaian kinerja kepada rekan kerja sebagai bagian dari evaluasi. Aplikasi system openunjang keputusan ini apat dikembangkan lagi sesuai dengan best practice sistem penilaian kinerja yang berlaku di setiap organisasi.

\section{DAFTAR PUSTAKA}

[1]. Elvina Lubis.(2013) .Sistem Pendukung Keputusan Penentuan Kelayakan Daerah Pertanian Menggunakan Metode SAW.

[2]. Wulandari, Ahmad Mustofa, Ponidi, Muhammad Muslihuddin, Firza Adi Firansyah. (2016). Decision Support System Pemetaan Lahan Pertanian Yang Berkualitas Untuk Meningkatkan Hasil Produksi Padi Menggunakan Metode Simple Additive Weighting (SAW) .SEMNASTEKNOMEDIA. AMIKOM Yogyakarta.

[3]. http://jurnalsdm.blogspot.co.id/2009/04/penilaian-kinerja-karyawan-definisi.html.

[4]. Dika Fitrika B. Sistem Pendukung Keputusan Pendeteksian Gizi Buruk Pada Balita Menggunakan Metode SAW.

[5]. http://fajarilhamsyah06111137.blogspot.co.id/2008/06/pengertian-dss-decision-support system.html

[6]. LPM, 2014, Pedoman Penilaian Kinerja Karyawan Universitas Muhammadiyah Purwokerto, Universitas Muhammadiyah Purwokerto, Purwokerto

[7]. Kusrini. 2007. Konsep dan Aplikasi Sistem Pendukung Keputusan. Yogyakarta: Andi

[8]. Borman, R.I., Helmi, F., 2018. Penerapan Metode Perbandingan Eksponensial (MPE) Dalam

Sistem Pendukung Keputusan Penerima Beasiswa Siswa Berprestasi Pada SMK XYZ, Journal of Computer Engineering, System and Science, Vol. 3, No. 1, no. ISSN : 2502-7131, p. 17-22.

[9]. Wulandari, Ahmad Mustofa, Ponidi, Muhammad Muslihuddin, Firza Adi Firansyah. (2016). Decision Support System Pemetaan Lahan Pertanian Yang Berkualitas Untuk Meningkatkan Hasil Produksi Padi Menggunakan Metode Simple Additive Weighting (SAW). SEMNASTEKNOMEDIA. AMIKOM Yogyakarta.

[10]. Sari, Bety Wulan .2015. Perbandingan Metode Profile Matching Dan Simple Additive Weighting Pada Penentuan Jurusan Siswa Kelas X SMA N 2 Ngaglik . Jurnal Ilmiah DASI Vol. 16 No. 1 Maret 2015, hlm 16-22. ISSN: 1411-3201

[11]. Afijal, dkk.2014. Decision Support System Determination for Poor Houses Beneficiary Using Profile Matching Method . Academic Research International Vol. 5(4) July 2014 . ISSN: 2223-9944, eISSN: 2223-9553.

[12]. S, Eniyati, 2011, Perancangan Sistem Pendukung Keputusan untuk Penerimaan Beasiswa dengan Metode SAW (Simple Additive Weighting). Jurnal Teknologi InHalamanasi DINAMIK. No.2, Volume 16, Juli 2011: 171-176.

[13]. Kusumadewi, dkk. 2006. Fuzzy Multi-Attribute Decision Making (Fuzzy MADM). Graha Ilmu, Yogyakarta. 
[14]. Ariyanto., 2012, Sistem Pendukung Keputusan Pemilihan Laryawan Terbaik Dengan Metode SAW (Simple Additive Weighting), Skripsi, Program Studi Teknik Informatika, Fakultas Teknik, Universitas Islam Negeri Sunan Kalijaga, Yogyakarta.

[15]. Supriyanti, W., 2014. Rancang Bangun Aplikasi Sistem Pendukung Keputusan Penerima Beasiswa dengan Metode SAW, Cite Journal, Vol.1 No.1, No. ISSN: 2534-5771.

[16]. Fishburn, P. C., 1967. A Problem based Selection of Multi Attribute Decision Making Methods, New Jersey: Blackwell Publishing.

[17]. Elvina Lubis.(2013).Sistem Pendukung Keputusan Penentuan Kelayakan Daerah PertanianMenggunakan Metode SAW. 